\title{
Pelvic Abscess
}

National Cancer Institute

\section{Source}

National Cancer Institute. Pelvic Abscess. NCI Thesaurus. Code C128331.

An abscess that is located in the pelvic cavity. 